\title{
Recruiting and Retaining Generation Y Teachers: Emerging Strategies for School Administrators
}

\author{
Sello Mokoena \\ Department of Teacher Education, University of South Africa, South Afric
}

\begin{abstract}
A generational transition is occurring in South African public school classrooms. Baby boom teachers (those born between 1946 and 1964) have begun to retire, and others from Generation $X$ (those born between 1965 and 1976) are entering their midcareer stage. The newest generation in the teaching profession is Generation Y (Gen Y). Attracting and retaining Gen $Y$ teachers into the teaching profession is a concern for many countries throughout the world. In South Africa, for example, about 45 per cent of those students who embark on the teaching courses never become teachers, and of those who do become teachers, about 30 per cent or more are no longer teaching five years later. This teacherturnover situation is often referred to as a "leaky bucket". In a research study conducted by the author entitled "student teachers expectations of teaching as a career choice in South Africa", it emerged that those who choose school teaching as a career have expectations about what teaching as a job will offer and if those expectations are not met, they leave the profession. Literature on talent management within and outside of the education sector suggests that keen attention must be given to Gen $Y$ teachers' needs and preferences to ensure that the most effective Gen $Y$ teachers continue to teach for more than just a few years. In the private sector, talent management policies and practices are being actively adapted to meet the needs of Gen $Y$ employees. Considering that the education sector is competing with many other sectors, it is crucial that the sector should consider taking strategic talent management approaches and addressing the needs of Gen $Y$ teachers. This article offers strategies to enhance teacher support and retention specifically for Gen $Y$ teachers.
\end{abstract}

\section{Introduction}

The challenge to recruit well-qualified teachers for South African public schools and to retain them is ever present. Each year about 10000 students enrol for different teaching programmes in the 23 public institutions of higher education in South Africa [5]. Popular training programmes for teachers are the Post-Graduate Certificate in Education (PGCE), an additional teaching qualification after a first degree, and the Bachelor of Education (BEd), an integrated four-year initial teacher education degree course [11].

The retention of student teachers on teaching programmes and to a point beyond their first few years as qualified teachers in the workplace has been an area of concern for the South African government and the Department of Higher Education and Training. South Africa needs at least 25000 new teachers every year in order to cope with learner demand. Every year the industry loses about 5\% of teachers as result of retirement, death, and people changing to other professions. There are currently 2 million learners, more than 350000 teachers and more than 30000 schools in 70 districts, in nine provinces [3].

Given the above shocking challenges, this article argues that teacher retention is the key to preventing teacher shortages facing South Africa. Drawing upon research from within and beyond education, this article describes what school administrators can do to enhance teacher support and retention - specifically for Generation Y (Gen Y) teachers. Considering that the education sector is competing with many other sectors for recruitment and retention of Gen Y talent, a literature review of private-sector practices revealed that the sector is already far ahead of the game in its efforts and strategies to recruit and retain this next generation of employees. The following themes emerged from this review: characteristics of Gen Y, private-sector strategies for Gen Y employees' retention and strategies for supporting Gen Y teachers. The aim is to help the state, education districts and school leaders better understand this generation so that they can better manage and support all teachers for the improvement of teaching and learning, for the current and future generations of students.

\section{Literature Review}

\subsection{Charact eristics of Generation $Y$}

David is a Gen Y teacher who has just taken a job in a local school district. During his interview, he was particularly disturbed by one of the questions posed: "How long do you expect to remain a teacher at this school?" He explained that he chose teaching as a career for life, and hoped that his skills and the fit in this particular school would enable him to be a 
lifelong teacher there. He then proceeded to ask why the question was posed, wondering if there was a high teacher turnover. The interviewer explained that of all Gen Y teachers they had hired in the last five years, approximately 75 percent left within three years. The turnover was becoming a huge problem for the school as it was creating instability among the staff, students, and parents. The principal, in particular, was worried about how this was affecting morale in the school and the school culture, never mind the intense cost and time for hiring every year.

After David started his job, he approached the principal again about this constant issue of turnover. He suggested that they meet to establish what might be working or not working for these new teachers (Gen Y teachers). During the course of the year, David and the principal established, among other things, a more modern mentoring programme, some professional development opportunity choices for newer teachers, and some guidelines for acceptable technological use within the school. David explained that as a Gen Y teacher, he expected all these things to be established in his new position. He was glad to help the principal start to evaluate some of the criteria by which Gen Y teachers may be judging the school, and to think about changes that would help integrate new teachers to the school (Adapted from [9]).

Although only a few research studies are available on Gen $\mathrm{Y}$ and cross-generational differences, the above extract does provide a sketch of typical Gen Y characteristics and workplace demands. One of the most important characteristics of Gen Y is the desire to trust authority [11]. Baby Boomers traditionally had little trust or admiration for authority and government. What Gen Y employees want from their leaders are examples of behaviours that can be admired, leading toward trust for those leaders. Admired behaviour is a powerful force that can transform a school into a true learning community where all employees feel appreciated and know that they can count on the goodness of intention when administrators make decisions that can affect their lives.

Another characteristic of Gen Y employees is that they tend to be highly educated and educationally minded; they typically attribute their success to their educational opportunities [17], [16]. Gen Y also are extremely comfortable with technology are dissatisfied with disconnected or technologically inferior work environment. Professionally, Gen Y employees are creative, innovative, and selfconfident. They like to share what they have learned through collaboration in small groups, and they are eager for their work to make a difference and contribute to a larger movement for positive change [2], [14], [18]. Like baby boomers (those born between 1946 and 1964), Gen Y employees tend to hold strong moral values, are connected to family and community, and are highly motivated to pursue a more open and tolerant society [10], [16]. Indeed, diversity is a part of their lives, much like technology, and in using technology (where ethnicity and gender are often invisible) they learn to work well together. They also spend a lot of money. Most Gen Y high school and college students have credit cards with fairly high limits. Companies market quite a lot to this age group, as there are so many Millennials with much spending power [6].

As can be seen by the lists generated above, there are many characteristics to cover about Gen Y. Probably the starkest difference between Gen Y and any other generation is the large, available access to information. All traditional university-age graduates entering workplaces as teachers during this era are from Gen Y. This generation believes that knowledge is power, and all knowledge can be found quickly through the Internet [16]. This group of individuals is particularly technology savvy. They blog, Google, and use Wikipedia to acquire sources of information. [6] believe that this new generation of graduating students will enter the workforce making changes as the baby boomer generation did during the 1960s. The young adults entering professions today are very ethnically diverse as well as dominated by females. They are typically eager to please others and work hard to achieve their goals in the process. Along with enjoying group work and community service they enjoy their families, expecting to live at home or near their parents as they enter the workforce [6]. With all of these characteristics in mind, [6] believe that there are seven core traits that can be identified for Gen Y and these include the following:

- $\quad$ They are made to feel they are special.

- They have been sheltered by their parents and society.

- $\quad$ They are confident with high levels of trust and optimism.

- $\quad$ They have developed strong team building skills (team-oriented).

- $\quad$ They are conventional, following rules and standards.

- $\quad$ They have been pressured to study hard and excel.

- They are high achieving and highly educated.

The characteristics described above provide some background knowledge about differences between Generation $\mathrm{Y}$ and previous generations. The following section discusses the approaches suggested by other fields (business sector) to address recruitment and retention of Generation $\mathrm{Y}$ professionals. 


\subsection{Private-sector strategies for Gen $\mathbf{Y}$ employees' retention}

Research has shown that in countries where there is intense competition in the labour market for newly qualified graduates, teaching has to compete with a host of other potential career choices [15], [7]. As such, the challenge to attract people to join the teaching profession, more especially Gen Y, is ever present. Although teacher recruitment and retention have been policy concerns for many years, most education-sector employers are still continuing to engage in the same recruitment, retention and leadership practices that have been in place for the past 50 years. Yet employers in other professions have been diligently addressing the effect of generational differences on human capital management. Although some limits exist regarding what can be transferred to education from other professions, several practices and strategies from the private sector can be helpful for the education field.

Many employers in the private sector have focused mainly on understanding their Gen Y employees. A survey conducted by Fidelity HR Services found that 80 percent of respondents from the business community believe that Generation $\mathrm{Y}$ talent is either "extremely important" or "very important" to the success of the business during the next five to 10 years [14]. In addition, a webcast poll of US companies conducted by the Human Capital Institute found that 21 percent of respondents already had implemented the strategies to recruit and retain Gen Y, 25 percent are considering doing so, and 36 percent currently are researching options to do so [14].

Again, a study of business leaders conducted by the global accounting firm KPMG International found that 69 percent of respondents from across the world indicated that they wished to better understand Gen Y employees, 35 percent already had developed strategies specifically targeted to aid Gen Y recruitment, and 36 percent already had developed strategies specifically targeted to aid Gen Y retention [13]. The private sector, as opposed to the education sector has adopted a number of strategies that specifically improve Gen Y retention. Among those identified strategies included the following: flexibility in work schedules, a high quality work environment, young talent programme to aid the career development of new employees, and young professional events for those under the age of 35 [13]. Those strategies that KPMG International researchers deemed most effective to attract and retain Gen Y included the following:

- Merit-based competition.

- Payment for higher education opportunities.

- Opportunities for career advancement.

According to [8], Gen Y workers typically desire relationships with their supervisors and colleagues, attractive salaries, opportunities for development, recognition for high quality work, exposure to challenging assignments, flexible working schedules, and casual dress in the workplace. Private sector companies with these benefits in place are likely to attract and retain Gen Y employees.

Based on other research survey findings, specialists at Deloitte Consulting LLP suggest that Gen Y employees want to feel connected, updated, included in decision-making processes and involved in their work [12]. In order to better engage and retain Gen Y employees, [12] suggested that managers do the following:

- Provide brief and regular updates so that Gen Y employees remain posted.

- Create authentic communications that are transparent and easily understood.

- Turn Gen Y employees into change agents by encouraging their valuable contributions.

- Develop mechanisms to generate great ideas from all members of staff.

In addition, [8] recommends the following seven strategies for retaining Gen Y employees:

- Encourage their values, individuality, and self-expression.

- $\quad$ Provide appropriate training as the basis for a job well done.

- $\quad$ Provide mentors, feedback and the reasons behind decisions.

- Convey how their work will make an impact on the company.

- Be fully honest and ethical with them.

- Create customised career paths that give them some control over their advancement as well as feedback on their progress.

- $\quad$ Provide the latest and best technology.

Many of these strategies are supported by and elaborated upon by staff at Fidelity HR Services [14]. They emphasise the importance of providing flexibility and customisation in work schedules, being honest and transparent, offering continuous feedback, and providing opportunities for Gen Y employees to work collaboratively in teams. They note, for instance, that mentoring for Gen $\mathrm{Y}$ is best provided by baby boomers rather than Generation $\mathrm{X}$ who often cannot understand Gen Y's needs for such guidance or support [14].

\section{Strategies for school administrators to support and retain Gen Y Teachers}

An immense body of literature, based on a perceptions survey suggests that educational leaders, school principals and administrators alike are responsible for establishing supportive conditions for the next generation of educators. Behrstock and Clifford [1] offers the following strategies to assist the government and the education districts as they 
grapple with the high attrition rate of Gen Y teachers. These strategies are summarised in Table 1:

Table 1. Strategies for supporting and retaining Gen Y teachers

\begin{tabular}{|c|c|c|}
\hline \multicolumn{2}{|r|}{ Strategy } & $\begin{array}{c}\text { Emphasis for Gen Y } \\
\text { Teachers }\end{array}$ \\
\hline 1 & $\begin{array}{l}\text { Establish a } \\
\text { shared vision } \\
\text { and set goals }\end{array}$ & $\begin{array}{l}\text { Involve Gen } \mathrm{Y} \text { teachers in } \\
\text { this process. }\end{array}$ \\
\hline 2 & $\begin{array}{l}\text { Encourage } \\
\text { shared } \\
\text { leadership }\end{array}$ & $\begin{array}{l}\text { Empower Gen Y teachers to } \\
\text { assume leadership } \\
\text { responsibilities from the Day } \\
1 .\end{array}$ \\
\hline 3 & $\begin{array}{l}\text { Create a } \\
\text { positive and } \\
\text { supportive } \\
\text { school } \\
\text { environment } \\
\end{array}$ & $\begin{array}{l}\text { Celebrate generational } \\
\text { differences and the unique } \\
\text { contributions of each. }\end{array}$ \\
\hline 4 & $\begin{array}{l}\text { Select and } \\
\text { assign teachers } \\
\text { effectively }\end{array}$ & $\begin{array}{l}\text { Realise that the career } \\
\text { ambitions and loyalties of } \\
\text { Gen teachers differ from } \\
\text { their predecessors. }\end{array}$ \\
\hline 5 & $\begin{array}{l}\text { ve } \\
\text { rs' skills, } \\
\text { edge, and } \\
\text { lities }\end{array}$ & $\begin{array}{lr}\text { Provide } & \text { professional } \\
\text { development } & \text { opportunities } \\
\text { that involve } & \text { collaboration } \\
\text { and technology. }\end{array}$ \\
\hline 6 & $\begin{array}{l}\text { Adopt effective } \\
\text { tool teacher } \\
\text { evaluation and } \\
\text { mentoring }\end{array}$ & $\begin{array}{l}\text { Offer in-depth feedback to } \\
\text { Gen Y teachers and offer } \\
\text { appraisal where needed. }\end{array}$ \\
\hline 7 & $\begin{array}{l}\text { Use time } \\
\text { effectively }\end{array}$ & $\begin{array}{l}\text { Set aside time for regular } \\
\text { collaboration with Gen Y } \\
\text { teachers }\end{array}$ \\
\hline 8 & hnology & $\begin{array}{l}\text { Create space for Gen Y } \\
\text { teachers to use technology to } \\
\text { improve instruction. }\end{array}$ \\
\hline 9 & $\begin{array}{l}\text { Ensure that } \\
\text { school facilities } \\
\text { are adequate } \\
\text { and functional } \\
\end{array}$ & $\begin{array}{l}\text { Ensure that adequate } \\
\text { facilities for latest } \\
\text { information technology are } \\
\text { available. }\end{array}$ \\
\hline 10 & $\begin{array}{l}\text { Provide } \\
\text { effective } \\
\text { instructional } \\
\text { leadership }\end{array}$ & 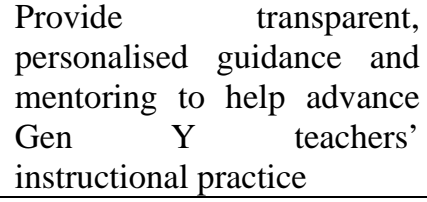 \\
\hline
\end{tabular}

(Adapted from [1])

\section{Conclusion}

To conclude, these strategies have yet to be studied and tested rigorously for their effectiveness in retaining talented Gen $\mathrm{Y}$ employees across different types of organisation; however, they may hold promise for school administrators hoping to recruit, support and retain Gen Y teachers.

\section{References}

[1] E. Behrstock and M. Clifford, Talent management practices in the private and education sectors: A literature review. Naperville, IL: Learning Point Associates, 2010.

[2] C. Carter and K. Carter, When generations collide [PowerPoint]. Johnson City, TN: East Tennessee State University, Employment Development Centre, 2001.

[3] Centre for Development and Enterprise: Informing South African Policy. Value in the classroom: The quantity and quality of South Africa's teachers, September 2011.

[5] L. Chisholm, Teacher supply and demand: research, policy and practice. HSRC, 2009.

[6] N. Howe and W. Strauss, Millennials Rising: The next generations. New York: Vintage Books, 2000.

[7] C. Kyriacou and M. Coulthard, Undergraduates' views of teaching as a career choice. Journal of Education for Teaching, 26(2), 2000, pp. 117-126.

[8] NAS Recruitment Communications, Generation Y: The millennials. Ready or not, here they come (NAS Insights). Cleveland, OH, 2006.

[9] R.W. Rebore and A.L.E. Walmsley, Recruiting and retaining Generation $Y$ teachers. London: Sage Publications, 2010.

[10] T.C. Reeves, Literature review: UPS/DOL new driver service provider training project. Atlanta, GA: United Parcel Service of America, 2006.

[11] Republic of South Africa (RSA), The National Policy Framework for Teacher Education and Development in South Africa. Government Gazette, 26 April 2007, No 29832. Pretoria: Government Printer, 2007.

[12] L. Reynolds, E.C. Bush and R. Geist, The Gen Y imperative. Communication World, 2008, pp. 19-22.

[13] B. Salt, Beyond the baby boomers: The rise of Generation $Y$-Opportunities and challenges for the funds management industry. Zurich, Switzerland: KPMG International, 2007.

[14] J. Shaffer, Gen Y talent: How to attract and retain the young and the restless (White Paper). Redwood Shores, CA: Saba, 2008.

[15] H. Stokes and D. Tyler, Senior secondary students' attitudes to teaching as a career: Review of teaching, 2003.

[16] H.K, Wong, R.T. Wong Teachers: The next generation. Alexandria, VA: Association for Supervision and Curriculum Development, 2007. 
International Journal for Cross-Disciplinary Subjects in Education (IJCDSE), Volume 3, Issue 1, March 2012

[17] H.K. Wong, R.T. Wong, Effective teaching: Training Gen $\mathrm{Y}$ teachers for maximum effectiveness. Teachers Net Gazette, 2007.

[18] J. Yuva, Corporations should know Y. Inside Supply Management, 2007, pp. 20-23. 